\title{
EFFECT OF INFANT MEAL HOME PREPARATION TEMPERATURE ON SURVIVING OF BACILLUS CEREUS SENSU LATO: A CASE OF BECHAR CITY, ALGERIA
}

- Research paper -

\author{
Hassiba DIFALLAH ${ }^{1}$, Mohammed ZIANE ${ }^{2,3 *}$, Olfa BEN BRAÏEK ${ }^{4}$, Mohammed BOUAMRA ${ }^{2}$, \\ Habiba LOUZIM ${ }^{5}$
}

\begin{abstract}
${ }^{1}$ Laboratoire de valorisation des ressources végétales et sécurité alimentaire dans les zones semiaride du Sud Ouest Algérien, Université de Bechar, Algérie

${ }^{2}$ Université de Ain Témouchent, route de Sidi bel abbès, N101, Ain Témouchent 46000, Algérie.

${ }^{3}$ Laboratoire de Microbiologie Appliquée à l'Agroalimentaire, au Biomédical et à l'Environnement

(LAMAABE), Faculté des SNV/STU, Université de, Tlemcen 13000 Tlemcen, Algérie

${ }^{4}$ Laboratory of Transmissible Diseases and Biologically Active Substances (LR99ES27), Faculty of

Pharmacy, University of Monastir, Tunisia

${ }^{5}$ MAHU, Laboratoire de pharmacie galénique, Faculté de Médecine de TLEMCEN, Université de

Tlemcen
\end{abstract}

\begin{abstract}
This work aimed to enumerate the Bacillus cereus sensu lato from infant's flour sampled at Béchar city and evaluate its resistance to different heating conditions during meal preparation patterns at home. Our findings revealed a prevalence of $74 \%$ with 2.4 to $3.9 \mathrm{CFU} / \mathrm{g}$ in the analyzed samples. Regarding the heat resistance at $90{ }^{\circ} \mathrm{C}$ to $98{ }^{\circ} \mathrm{C}$, our results showed heat resistance variability which depends on the isolate, for example, $\mathrm{D}_{90}{ }^{\circ} \mathrm{C}$ and $\mathrm{z}_{\mathrm{T}}{ }^{\circ} \mathrm{C}$ values varied from 3.24 to $5.52 \mathrm{~min}$ and 11.56 to $89.74{ }^{\circ} \mathrm{C}$ respectively. Then, the decimal reduction (n) was calculated at all preparation temperatures $\left(50,60,70,80,90\right.$ and $\left.100{ }^{\circ} \mathrm{C}\right)$. Low " $\mathrm{n}$ " was observed with the preparation at $\mathrm{T} \leq 50{ }^{\circ} \mathrm{C}$ as recommended by the fabricant. However, at the other temperatures, high " $n$ " was observed at $100^{\circ} \mathrm{C}$ with median and $95^{\text {th }}$ values of 2.22 and 12.36 respectively. Therefore, bacterial concentrations $\left(99^{\text {th }}\right)$ were estimated at $0.124 \log \mathrm{CFU} / \mathrm{g}$ for $100{ }^{\circ} \mathrm{C}$. These concentrations could be increased with bacterial growth during meal storage and then achieve critical concentrations. Thus, the results of this work highlight the interest to establish a risk assessment for babies and to improve the production, preparation, and storage conditions of the infant's flour.
\end{abstract}

Keys words: Inactivation modeling, Bacillus cereus, Infant powders, Risk assessment

\section{INTRODUCTION}

Since the baby's birth, his feeding is closely linked to breast milk feeding, which provides him an important source of effective infant nutrition for his growth. In addition, it minimizes the risk of allergy, obesity, and intestinal diseases, favors good digestion, and brings antimicrobial factors by supporting infants' immune system (Jackson and Nazar, 2006).

In spite of its importance, breast milk is insufficient to cover the infant needs during the weaning period (Clark and Shrimpton, 2000). Therefore, to ensure the best nutrition for infants, food complementary feeding was introduced as known as the infant's milk formula and the infant's

Received: 28.09 .2021

Accepted in revised form: 30.11 .2021 flour. The infant's milk formula is a substitute of breast milk while the infant's flour could ensure his needs.

In Algeria, the consumption of industrial infant's flour has increased in these last years. Most of the industrial infant's flours commercialized in Algeria are mixtures of several cereals (such as wheat, barley, rye, rice, and corn), mineral complexes, vitamin complexes, sugar, protein and lipids (collected from different labels). This food with low water activity $\left(\mathrm{a}_{\mathrm{w}}<0.5\right)$ is based on one or several cereal ingredients' ground and dried after being washed to lower their moisture content (NutriFaso, 2007). The wire netting of grains, before fragmentation and dilution in some water or some milk, is made in an oven or a roaster (Sanogo et al., 1994). It is not a sterile product which can contain microorganisms. With its low $\mathrm{a}_{\mathrm{w}}$, bacteria

* Corresponding author. E-Mail address: ziane.mohammed@yahoo.fr 
could not grow, but this fact does not mean the absence of spores forming bacteria because the roasting treatment is not able to eliminate this type of bacteria. Bacillus cereus is one of the bacteria that could survive at these conditions. It could be activated and germinate during preparation conditions (hydration and warm water), then could grow during storage to reach a critical concentration (5 $\log \mathrm{CFU} / \mathrm{g}$ ). Indeed, at this concentration, B. cereus could produce a harmful toxin in the food or in the intestine that is involved in emetic or diarrheal syndromes, respectively (Cadel Six et al., 2012; Savic et al., 2020). Furthermore, it is important to denote that the symptoms caused by these bacteria groups are confused with those caused by Staphylococcus aureus and Clostridium perfringens (Cadel Six et al., 2012). As a precautionary measure for the baby's preparation, Algerian standards recommend to check B. cereus with a maximum limit of $2.7 \mathrm{log}$ CFU/g (JORAD N³9 2017). Otherwise, the manufactures require a temperature preparation between $45-50^{\circ} \mathrm{C}$. Unfortunately, at this temperature range, $B$. cereus survives, and thereafter could grow in meal. Ziane et al. (2019) showed that $B$. cereus survives at two and three steaming cycles of couscous semolina at

\section{MATERIALS AND METHODS}

\section{Sampling procedure}

To check the infant's flour brands sold in Béchar city, the sampling was conducted at various sale points (grocery stores and pharmacies). Hence, the sampling method was used to spot a random sale point on the map of Béchar city as described by Grawitz (2001). The preparation pattern has been collected from manufacturer's instructions listed on the container of each brand and baby minder behaviors, only for families having a baby. Each preparation pattern defines a scenario.

\section{Microbiological analysis of infant's flour Detection \& enumeration of B. cereus sensu lato Sampling and processing}

A total of 70 infant's flour samples with 10 different brands and various tastes were collected from 20 selected sale points, and then transferred to the laboratory in their sold conditions for microbiological analysis. The outside surface of the infant's flour bag was disinfected with alcohol (99.8\%) and then opened in aseptic conditions. From each sampling unit, $10 \mathrm{~g}$ were taken and diluted in $90 \mathrm{~mL}$ of peptone water. The mixture was then put in a water bath at $80^{\circ} \mathrm{C}$ for $10 \mathrm{~min}$ to temperatures ranging from 98 to $100{ }^{\circ} \mathrm{C}$ and then grows in the couscous meal. Therefore, different questions could be asked at this level and require further study to obtain accurate answers such as: Does the temperature recommended by fabricant eliminate $B$. cereus in the meal? Do the baby minders follow the fabricant's instructions? Is the baby minder preparation safer than that recommended by the fabricant? Does it necessary to improve a preparation pattern? Thus, this paper aims to assess (1) the preparation patterns of meals based on infant's flour according to different actors (fabricant instructions and baby minders), (2) their heat resistance, (3) the decimal reduction ratio at each preparation temperature, and (4) the concentration of B. cereus sensu lato in the infant's flour meal. In this context, it should be important to denote that the B. cereus sensu lato is a group of bacteria belonging to Bacillus gender and displaying close phylogenetic relationship but are affiliated to different phylogenetic sub-groups (I to VII) with high ecological diversity (Guinebretière et al., 2008). This group includes $B$. pseudomycoides, $B$. weihenstephanensis, $B$. mycoides, Bacillus anthracis, Bacillus cereus sensu stricto, Bacillus cytotoxicus and Bacillus thuringiensis (Guinebretière et al., 2008).

eliminate the vegetative flora and select only the spore forming bacteria.

Isolation and enumeration of B. cereus sensu lato bacteria

The serial decimal dilutions were made in peptone water from the previously heated mixtures. A volume of $0.1 \mathrm{~mL}$ of each dilution was spread over the surface of Mossel Agar plates (Tryptone (10.0 $\mathrm{g})$; Meat extract (1.0 g); D-mannitol (10.0 g); Sodium chloride (10.0 g); Phenol red (25.0 mg); Sterile egg yolk emulsion $(100,0 \mathrm{~mL})$; Bacteriological agar (13.5 g); pH $7.2 \pm 0.2$ ) (Biokar diagnostics, France), then incubated at $30^{\circ} \mathrm{C}$ for $24 \mathrm{~h}$ for isolation and enumeration. $B$. cereus sensu lato are Gram positive, rod shaped, catalase positive, and endospores forming.

\section{Determination of $B$. cereus sensu lato heat resistance \\ Production of spore stock}

A volume of $0.5 \mathrm{~mL}$ from the preculture was spread over the surface of nutrient agar medium (Biokar diagnostics, Beauvais, France) supplemented with $40 \mathrm{mg} / \mathrm{L}$ of $\mathrm{MnSO}_{4}$ and 100 $\mathrm{mg} / \mathrm{L}$ of $\mathrm{CaCl}_{2}$, then incubated at $30{ }^{\circ} \mathrm{C}$ for the time necessary for the sporulation of the seeded 
bacterial population. The sporulation was monitored by observation under the phase contrast microscope for 5 days of incubation. The spores of B. cereus sensu lato were then harvested using a sterile spatula by scraping the agar surface. The recovered spores were suspended in $20 \mathrm{~mL}$ of sterile distilled water. The prepared spore suspension was centrifuged at $500 \times g$ for $30 \mathrm{~min}$. The pellet was collected and resuspended into 20 $\mathrm{mL}$ of sterile distilled water. This operation was repeated twice. The obtained pellet was taken up in a water/ethanol (v/v) mixture and placed at $4^{\circ} \mathrm{C}$ for $12 \mathrm{~h}$ to remove the rest of the vegetative forms. The mixture was then centrifuged at $500 \times g$ for 30 min. The treated pellets underwent three washing cycles with sterile distilled water under the same conditions of centrifugation. The pellets previously recovered were then resuspended in a minimum volume above $200 \mu \mathrm{L}$ of sterile distilled water to have thus a high concentration of spores. The stock of $B$. cereus sensu lato spores obtained was stored for a minimum one month at $4^{\circ} \mathrm{C}$ in distilled sterile water before the heat treatment step.

\section{Thermal treatment}

A volume of $100 \mu \mathrm{L}$ of spore stock was suspended in $10 \mathrm{~mL}$ of BHI (Brain Heart Infusion Broth) (Biokar diagnostics, Beauvais, France). Then, a volume of $1 \mathrm{~mL}$ was distributed in sterile tubes. After heating at different temperature ranged from $90^{\circ} \mathrm{C}$ to $98^{\circ} \mathrm{C}$, the content of each tube was quickly poured into $9 \mathrm{~mL}$ of sterile physiological water. Survival spore enumeration was carried out by inclusion of $0.5 \mathrm{~mL}$ of heated tubes content into 15 $\mathrm{mL}$ nutrient agar, then incubated at $37^{\circ} \mathrm{C} 48 \mathrm{~h}$.

\section{Determination of heat resistance parameters}

Heat resistance parameters were estimated by the first order kinetic (Equation 1).

$$
\log N_{t}=\log N_{0}-\left(\frac{t}{D_{T^{\circ} \mathrm{C}}}\right)
$$

$\mathrm{N}_{0}$ represents the initial number of cells, $\mathrm{N}_{\mathrm{t}}$ is the number of cells at time $t, \mathrm{D}_{\mathrm{T}}{ }^{\circ} \mathrm{C}$ is a time that leads to a 10 -fold reduction of surviving population. Otherwise, the influence of temperature $\left(\mathrm{T}^{\circ} \mathrm{C}\right)$ on bacterial heat sensitivity was quantified by the classical sensitivity parameter $z_{T}{ }^{\circ} \mathrm{C}$ as shown in Equation 2 (Bigelow, 1921):

$\log D_{T^{\circ} \mathrm{C}}=\log D_{T^{\circ} C_{\text {mean }}}-\left(\frac{T^{\circ} \mathrm{C}-T^{\circ} C_{\text {mean }}}{z_{T^{\circ} \mathrm{C}}}\right)$

$z_{T}{ }^{\circ} \mathrm{C}$ corresponds to a temperature $\left({ }^{\circ} \mathrm{C}\right)$ increase that leads to a ten-fold reduction of $\mathrm{D}_{\mathrm{T}}{ }^{\circ} \mathrm{C}-\mathrm{value}, \mathrm{D}_{\mathrm{T}}$ ${ }^{\circ} \mathrm{Cmean}$ is a scale parameter (minutes) estimated from the mean of heating temperature $\mathrm{T}^{\circ} \mathrm{C}_{\text {mean }}\left({ }^{\circ} \mathrm{C}\right)$ tested in this study.
Estimation of concentration at the end of each preparation step

\section{Collection of temperature preparation}

During meal preparation, lukewarm boiled water (or milk) was added to the infant's flour and then mixed. As a dry product, the infant's flour absorbs quickly the added lukewarm boiled (heating) water (or milk) to achieve the maximum temperature $\left(\mathrm{T}_{\max }\right)$ in the meal, then decreases by cooling.

The preparation way was collected from 100 families. The persons were asked the following questions: (1) Do you respect the meal preparation instructions labeled by the sold brand? (2) Do you know exactly the temperature used for such preparation? (3) If yes, what is it? (4) If no, what is the range of the used temperature: $\left[60-80{ }^{\circ} \mathrm{C}\right]$ or $\left[80-100{ }^{\circ} \mathrm{C}\right]$ ? As for the temperature recommended by the manufacture, it was collected from label instructions $\left(45^{\circ} \mathrm{C}\right.$ and $\left.50^{\circ} \mathrm{C}\right)$.

\section{The temperature profile modeling}

To evaluate the temperature profile for all used temperatures (scenarios), the thermometer was emerged in the middle point. To do it, the meal was prepared as follows: a volume of $150 \mathrm{~mL}$ of heated water (at the studied temperature for each scenario and collected data) was gradually added to $30 \mathrm{~g}$ of infant's flour in the bottle and mixed well to record temperature profile each 1 minute.

\section{Estimation of decimal reduction ratio during preparation}

When the temperature profile was recorded, the decimal reduction ratio " $\mathrm{n}$ " was estimated at each temperature $\left(\mathrm{T}^{\circ} \mathrm{C}\right)$ kinetic. The Bigelow method was used, based on calculating the partial biological destruction value $(\mathrm{L}(\mathrm{T})$ ) for each temperature kinetic recorded every minute. Then, the decimal reduction ratio $\left(\mathrm{n}_{\mathrm{T}}{ }^{\circ} \mathrm{C}\right)$ was calculated according to the equation 4 . The $\mathrm{L}(\mathrm{T})$ were calculated throughout the time spend for the temperature to reach $45{ }^{\circ} \mathrm{C}$. For each onset temperature $\left(\mathrm{T}{ }^{\circ} \mathrm{C}\right)$ these times were calculated basing on challenge test.

$\left.L(T)=10^{\left(T^{\circ} \mathrm{C}-T_{\text {mean }}\right)} / z_{T^{\circ} \mathrm{C}}\right)$
$n=\sum L(T) / D_{T^{\circ} \text { Cmean }}$

\section{Statistical analysis}

The heat resistance parameters $\left(\mathrm{D}_{\mathrm{T}}{ }^{\circ} \mathrm{C}\right.$ and $\mathrm{z}$-values), biological destruction $\mathrm{L}(\mathrm{T})$, and decimal reduction ratio (n) were estimated using Excel in Microsoft office. The probabilistic distribution, fitting and Monte Carlo simulation were carried out by @Risk software version 5 (Palisade). As for ANOVA analysis, SPSS software version 22 was used. 


\section{RESULTS}

Distribution of $B$. cereus sensu lato in analyzed infant's flour samples

The presumptive colonies of B. cereus sensu lato are pink and surrounded by an opaque zone due to the mannitol fermentation inability and lecithinase production capacity, respectively.

As for the contamination level in this study, the median concentration ranged between 2.4 to 3.9 $\log \mathrm{CFU} / \mathrm{g}$

\section{Heat resistance parameters of $B$. cereus sensu lato}

To estimate the heat resistance parameters $\left(\mathrm{D}_{\mathrm{T}}{ }^{\circ} \mathrm{C}\right)$, the linear regression was adopted for each isolate using the whole set of curves. The results are summarized in Table 1. Results show heterogeneity in heat resistance of the studied isolates. The $\mathrm{D}_{\mathrm{T}}{ }^{\circ} \mathrm{C}$ values belongs from 3.24 to 5.52 , for e.g. $95^{\circ} \mathrm{C}$. As for the heat sensitivity, heat treatments were carried out and varied from $11.56^{\circ} \mathrm{C}$ to $89.74^{\circ} \mathrm{C}$.

Estimation of decimal reduction ratio at different preparation temperatures

\section{Meal preparation temperature}

As summarized in Table 2, most manufacturers recommend heating the water then letting the temperature drop to $45^{\circ} \mathrm{C}$, while no heat treatment is required when using milk for meal preparation. Sixteen percent of the meal preparations used cool or ambient temperature milk and $70 \%$ heated it. Others add spices (1.1\%) as well as fruits and vegetables $(9.8 \%)$. The manufacturing does not recommend the use of heated milk may be, to preserve its components and because it underwent a previous sterilization during its production process. According to the objectives of this study, the using frequency is not necessary.

According to a survey conducted in this study, only $41.5 \%$ of baby minders respect the recommendations to prepare the infant meal as established by the manufacturers (Table 2), whereas, $49 \%$ of them do not respect the label instructions. In fact, these latter baby minders have no information about the safety preparation pattern and they prefer using hot water (more than $60^{\circ} \mathrm{C}$ ) to ensure the death of the likely present microbes (as they called) in the infant's flour without taking into account the guarantee of the nutritional quality of the prepared meals. Effectively, 37.5\% and 5.8\% of baby minders prepared the infant meal with water heated at $60-80^{\circ} \mathrm{C}$ and $80-100^{\circ} \mathrm{C}$, respectively.
Exposure time during meal preparation

Regarding the exposure time, it depends on the initial temperature. It is the spent time (min) required to achieve the consumption temperature above $45^{\circ} \mathrm{C}$. As shown in Table 2, exposure times were calculated for each temperature $\left(50^{\circ} \mathrm{C}, 60^{\circ} \mathrm{C}\right.$, $\left.70^{\circ} \mathrm{C}, 80^{\circ} \mathrm{C}, 90^{\circ} \mathrm{C}, 100^{\circ} \mathrm{C}\right)$. They were used to calculate the biological destruction value $(\mathrm{L}(\mathrm{T}))$.

\section{Temperature profile in the meal preparation}

Regardless the tested temperature, the meal temperature decreases. For temperature $<50{ }^{\circ} \mathrm{C}$, the temperature directly achieves the $45^{\circ} \mathrm{C}$ in 3 min. Moreover, similar observations were noted for scenario 2, when the baby minders $(41.7 \%)$ respect the manufacturer's instruction. Thus, the same effect could be carried out. As for temperatures 65 and $70^{\circ} \mathrm{C}$, they decrease respectively from $54^{\circ} \mathrm{C}$ and $61^{\circ} \mathrm{C}$ to $45^{\circ} \mathrm{C}$ during a recorded time of 10 and 14 minutes respectively.

Estimation of the decimal reduction ratio of $B$. cereus sensu lato in the meal

The biological destruction value $(\mathrm{L}(\mathrm{T}))$ was calculated for each temperature kinetic and tested isolate. $\mathrm{L}(\mathrm{T})$ was proportional to temperature. The results showed that the high values were observed for $100^{\circ} \mathrm{C}$ (median $=5.40$; mean $\left.=7.36 ; 95^{\text {th }}=19.92\right)$. Then, these values were used to calculate the decimal reduction ratio " $n$ " at each temperature. "n" values were dependent to the preparation temperature and $\mathrm{L}(\mathrm{T})$, as reported in Table 2 . However, lowest temperature effect was estimated for temperature $<50{ }^{\circ} \mathrm{C}$. As shown in Table 2, high values were reported at $100^{\circ} \mathrm{C}$ (median $=2.22$; mean $=3.16 ; 95^{\text {th }}=12.35$ ), while low ones at $50^{\circ} \mathrm{C}$ (median $=0.02=$ mean; $95^{\text {th }}=0.35$ ).

\section{DISCUSSION}

It is noted that the prevalence $(74 \%)$ of $B$. cereus sensu lato seemed to be similar to the prevalence (78\%) reported by Heini (2018) and higher than $3.5 \%$ reported by Zhang et al. (2017). As for their concentrations in analyzed samples, they were in concordance with those reported (3 to $4 \log$ $\mathrm{CFU} / \mathrm{g}$ ) by Zhang et al. (2017). The presence of $B$. cereus sensu lato in analyzed samples is evident because (1) the infant flour is not a sterile product, (2) and is produced with various ingredients that are generally contaminated by $B$. cereus group.

In fact, several infant's flour ingredients are contaminated by $B$. cereus sensu lato mainly rice (Sarrias et al. 2002), maize (Byaruhanga et al. 1999), wheat (Valerio et al. 2012) or oats and other cereals (Daczkowska-Kozon et al. 2009). The $B$. 
cereus sensu lato group is mostly present in raw materials, which increases its probability and/or confirms its occurrence in the infant's flour.

The presence of B. cereus sensu lato in the infant's flour could be due to several factors: (1) the contaminated raw material, (2) the ability of $B$. cereus sensu lato to produce a spore form to survive in hostile conditions, especially at low $\mathrm{a}_{\mathrm{w}}$ of this product (infant's flour). Fortunately, at this step, the B. cereus sensu lato is not exceeding a critical concentration (5 log $\mathrm{CFU} / \mathrm{g}$ ) and could decrease after preparation with warm boiling water depending to the preparation patterns.

The problem is not related only to the $B$. cereus sensu lato existence in the product, but also to (1) its heat resistance and ability to grow and achieve a critical concentration ( $5 \mathrm{log}$ cells per g) and (2) low temperature of preparation for both patterns (manufacturing instructions and baby minder preparation). Thus, the $B$. cereus level could increase particularly when they survive and growth during preparation and storage respectively. In fact, Sadek et al. (2018) considered infant's formula as an excellent medium for a bacterial growth. Buss da Silva et al. (2017) showed the growth of three tested strains of $B$. cereus in reconstituted infant formula. Otherwise, Messelhäusser et al. (2014) reported that cereal-based infant food formula, rich in vitamins and trace elements, is known to promote cereulide synthesis.

According to the rarety of studies in this field, it could be given as example, the couscous semolina as similar product (low $\mathrm{a}_{\mathrm{w}}$ and heating preparation). In this context, Ziane et al. (2019) reported the growth of $B$. cereus in couscous semolina after streaming at $>90^{\circ} \mathrm{C}$ for two or three cycles during above $15 \mathrm{~min}$ (a heating condition more severe than that using for infant flour meal preparation). These results depended on the storage and waiting time. Thus, the waiting time to finish a meal is important to prevent against obtaining unsafe meal or exposing baby to critical concentration of toxigenic B. cereus.

As for the heat resistance of tested strains of $B$. cereus sensu lato, the $\mathrm{D}_{95}{ }^{\circ} \mathrm{C}$ values are in disagreement with those (4.4-8.4 $\mathrm{min}$ and 0.68$18.85 \mathrm{~min}$ ) reported by Stoeckel et al. (2013) and Ziane et al. (2014) respectively. According to our findings, the heat resistance is strain dependent, similar to the results exposed by Ziane et al. (2014) and Ziane et al. (2016). Otherwise, teh $\mathrm{z}_{\mathrm{T}}{ }^{\circ} \mathrm{C}$ values were higher than those reported by Mazas et al. (1999), Janštová and Lukášová (2001), and Montville et al. (2005), which ranged from $7{ }^{\circ} \mathrm{C}$ to $13{ }^{\circ} \mathrm{C}$.

The previously heat resistance parameters were used to estimate the decimal reduction number " $n$ " at different scenario. As a matter of fact, the low "median of 0.02" was reported for the low temperature preparation recommended by fabricant.

Unfortunately, temperature recommended by fabricant is insufficient to reduce significant the $B$. cereus concentration (Table 3 ).

The B. cereus sensu lato concentration at different preparations was estimated by Equation 5 developed by Nauta (2001) and Membré and Valdramidis (2016). The probabilistic approach was used to simulate the B. cereus sensu lato concentration using Poisson distribution:

$[\text { B. cereussl }]_{s}=$ Riskpoisso $\left([\text { B. cereus sl }]_{0} \times m_{0} \times 10^{-n}\right)$

where

$\left[\begin{array}{lll}\text { B. cereus } & s l\end{array}\right]_{\mathrm{s}}$ : survival concentration (CFU per prepared amount) of B. cereus sensu lato in the meal after heating;

$[B . \quad \text { cereus } s]_{0}$ : Distribution of the initial concentration (CFU per gram of analyzed infant's flour) of $B$. cereus sensu lato. It was fitted by RiskDuniform $\left(\mathrm{C}_{1}, \mathrm{C}_{2}, \mathrm{C}_{3}, \ldots, \mathrm{C}_{\mathrm{i}}\right) \quad \times \quad$ RiskBeta (number of contaminated samples +1 , no contaminated samples+1). $\mathrm{C}_{1}$ to $\mathrm{C}_{\mathrm{i}}$ are the concentrations of $B$. cereus sensu lato in each positive sample (1 to i respectively). As for the probability of toxigenic strains occured among these concentrations, the RiskUniform $(0 ; 1)$ distribution was used. The results were reported in Table 2. In the absence of information about distribution of toxigenic bacteria among $B$. cereus group, it was assumed that toxigenic B. cereus could represent any percentage (varying from 0 to $100 \%$ ) of all group of B. cereus that was therefore described by a RiskUniform $(0 ; 1)$ as shown by Ziane et al. (2019).

$\mathrm{n}$ : corresponds to the decimal reduction ratio, that was estimated for each isolate at each temperature. The " $n$ " values were derived from Equation 5 of RiskDuniform distribution (RiskDuniform $\left.\left(n_{1}, n_{2}, \ldots . . n_{12}\right)\right)$, with the index of " $n$ " representing the isolate number that varied from 1 to 12 .

$m_{0}$ : quantity $(\mathrm{g})$ of infant flour in package $(250 \mathrm{~g})$.

Because the isolates were not affiliated in their toxigenic groups to have information about their pathogenicity, thus, they were assumed to exhibit toxigenic groups with equiprobability. It was implemented in the estimation of RiskUniform $(0 ; 1)$. 


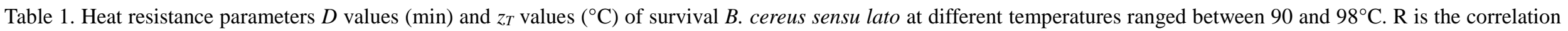
coefficient. Confidence intervals at $95 \%$ are given in brackets. Confidence intervals of $\mathrm{z}$-values are not significant.

\begin{tabular}{|c|c|c|c|c|c|c|c|c|c|c|c|}
\hline $\begin{array}{l}\text { B. cereus } \\
\text { IF1 }\end{array}$ & B. cereus IF2 & $\begin{array}{l}\text { B. cereus } \\
\text { IF3 }\end{array}$ & $\begin{array}{c}\text { B. cereus IF } \\
4\end{array}$ & $\begin{array}{l}\text { B. cereus } \\
\text { IF } 5\end{array}$ & $\begin{array}{l}\text { B. cereus } \\
\text { IF } 6\end{array}$ & $\begin{array}{c}\text { B. cereus IF } \\
7\end{array}$ & $\begin{array}{c}\text { B. cereus IF } \\
8\end{array}$ & $\begin{array}{c}\text { B. cereus IF } \\
9\end{array}$ & $\begin{array}{l}\text { B. cereus } \\
\text { IF } 10\end{array}$ & $\begin{array}{l}\text { B. cereus IF } \\
11\end{array}$ & $\begin{array}{l}\text { B. cereus IF } \\
12\end{array}$ \\
\hline 3.24 & 4.95 & 4.95 & 5.52 & 4.9 & 3.87 & 4.45 & 5.15 & 3.72 & 5.25 & 5.24 & 5.4 \\
\hline$[3-3.48]$ & {$[4.49-5.41]$} & $\begin{array}{c}{[4.12-} \\
5.78]\end{array}$ & [4.75 - 6.29] & $\begin{array}{c}{[4.37-} \\
5.43]\end{array}$ & $\begin{array}{c}{[3.49-} \\
4.25]\end{array}$ & {$[4.38-4.52]$} & {$[4.19-6.11]$} & {$[3.23-4.21]$} & $\begin{array}{c}{[4.67-} \\
5.83]\end{array}$ & [4.6 - 5.88] & {$[4.44-6.36]$} \\
\hline $\mathrm{R}^{2}=0.981$ & $\mathrm{R}^{2}=0.983$ & $\mathrm{R}^{2}=0.947$ & $\mathrm{R}^{2}=0.962$ & $\mathrm{R}^{2}=0.977$ & $\mathrm{R}^{2}=0.987$ & $\mathrm{R}^{2}=0.999$ & $\mathrm{R}^{2}=0.985$ & $\mathrm{R}^{2}=0.967$ & $\mathrm{R}^{2}=0.938$ & $\mathrm{R}^{2}=0.971$ & $\mathrm{R}^{2}=0.94$ \\
\hline 2.96 & 3.05 & 3.59 & 3.21 & 3.16 & 2.77 & 3.05 & 3.08 & 1.52 & 3.17 & 4.62 & 1.76 \\
\hline
\end{tabular}

\begin{tabular}{|c|c|c|c|c|c|c|c|c|c|c|c|c|}
\hline \multirow[t]{3}{*}{$\begin{array}{l}D_{95}{ }^{\circ} \mathrm{C} \\
(\min )\end{array}$} & $\begin{array}{l}{[2.91-} \\
3.01]\end{array}$ & [2.77 - 3.33] & $\begin{array}{c}{[3.34-} \\
3.84]\end{array}$ & [3.13 -3.29] & [2.85-3.47] & [2.67-2.87] & [2.84-3.26] & [2.96-3.2] & [1.51-1.53] & [2.67-3.67] & [3.56-5.68] & [1.51-2.01] \\
\hline & $\mathrm{R}^{2}=0.993$ & $\mathrm{R}^{2}=0.983$ & $\mathrm{R}^{2}=0.99$ & $\mathrm{R}^{2}=0.999$ & $\mathrm{R}^{2}=0.982$ & $\mathrm{R}^{2}=0.997$ & $\mathrm{R}^{2}=0.99$ & $\mathrm{R}^{2}=0.997$ & $\mathrm{R}^{2}=0.91$ & $\mathrm{R}^{2}=0.982$ & $\mathrm{R}^{2}=0.905$ & $\mathrm{R} 2=0.987$ \\
\hline & 1.38 & 1.99 & 2.97 & 2.12 & 2.87 & 1.76 & 2.85 & 2.77 & 1.02 & 2.16 & 4.26 & 1.12 \\
\hline \multirow[t]{2}{*}{$\begin{array}{l}D_{98}{ }^{\circ} \mathrm{C} \\
(\min )\end{array}$} & $\begin{array}{c}{[1.23-} \\
1.53]\end{array}$ & {$[1.8-2.19]$} & $\begin{array}{c}{[2.59-} \\
3.35]\end{array}$ & [1.93 - 2.31] & $\begin{array}{c}{[2.53-} \\
3.21]\end{array}$ & $\begin{array}{c}{[1.26-} \\
2.26]\end{array}$ & [2.75-2.95] & {$[2.46-3.08]$} & {$[0.79-1.25]$} & $\begin{array}{l}{[2.01-} \\
2.31]\end{array}$ & [4.17 - 4.37] & {$[0.96-1.28]$} \\
\hline & $\mathrm{R}^{2}=0.989$ & $\mathrm{R}^{2}=0.9$ & $\mathrm{R}^{2}=0.969$ & $\mathrm{R}^{2}=0.992$ & $\mathrm{R}^{2}=0.972$ & $\mathrm{R}^{2}=0.986$ & $\mathrm{R}^{2}=0.998$ & $\mathrm{R}^{2}=0.997$ & $\mathrm{R}^{2}=0.987$ & $\mathrm{R}^{2}=0.991$ & $\mathrm{R}^{2}=0.972$ & $\mathrm{R}^{2}=0.987$ \\
\hline \multirow{2}{*}{$\begin{array}{l}\mathrm{z}_{\mathrm{T}} \text {-value } \\
\left({ }^{\circ} \mathrm{C}\right)\end{array}$} & 21.80 & 20.58 & 36.04 & 19.43 & 33.37 & 24.17 & 39.89 & 28.75 & 14.11 & 20.96 & 89.74 & 11.56 \\
\hline & $=0.9954$ & $\mathrm{R}^{2}=0.9889$ & $\mathrm{R}^{2}=1$ & $\mathrm{R}^{2}=0.9956$ & $\begin{array}{c}R^{2}= \\
0.9563\end{array}$ & $\begin{array}{c}R^{2}= \\
0.9478\end{array}$ & $\mathrm{R}^{2}=0.9442$ & $\mathrm{R}^{2}=0.9525$ & $\mathrm{R}^{2}=0.9942$ & $\begin{array}{c}R^{2}= \\
0.9959\end{array}$ & $\mathrm{R}^{2}=0.9998$ & $\mathrm{R}^{2}=0.9904$ \\
\hline
\end{tabular}

Table 2. Estimation of biological destruction value $\mathrm{L}(\mathrm{T})$, decimal reduction number (n).

\begin{tabular}{|c|c|c|c|c|c|c|c|c|c|c|c|}
\hline & \multirow[b]{2}{*}{$\%$} & \multirow{2}{*}{\multicolumn{2}{|c|}{$\begin{array}{l}\text { Temperature } \mathrm{T} \\
\left({ }^{\circ} \mathrm{C}\right)\end{array}$}} & \multirow{2}{*}{$\begin{array}{c}\text { Maximum } \\
\text { temperature in } \\
\text { meal }\end{array}$} & \multirow{2}{*}{$\begin{array}{l}\text { Time need to achieve } \\
\text { temperature } \\
\text { consumption } 45^{\circ} \mathrm{C}\end{array}$} & \multicolumn{3}{|c|}{$\mathrm{L}(\mathrm{T})$} & \multicolumn{3}{|c|}{ Decimal reduction number "n" } \\
\hline & & & & & & mean & median & $95^{\text {th }}$ & mean & median & $95^{\text {th }}$ \\
\hline Label instruction & $/ /$ & $\leq 5$ & & 47 & 4 & 0.24 & 0.06 & 1.62 & 0.02 & 0.02 & 0.35 \\
\hline \multirow{6}{*}{ Baby minder } & 41.7 & $\leq 5$ & & & & & & & & & \\
\hline & 5.8 & $60-80$ & 60 & 54 & 10 & 0.62 & 0.18 & 3.72 & 0.18 & 0.10 & 0.79 \\
\hline & & & 70 & 61 & 14 & 1.08 & 0.40 & 5.79 & 0.33 & 0.20 & 1.23 \\
\hline & 37.5 & $80-100$ & 80 & 68 & 17 & 1.99 & 0.95 & 9.12 & 0.67 & 0.42 & 1.94 \\
\hline & & & 90 & 78 & 30 & 4.80 & 3.06 & 16.71 & 1.83 & 1.23 & 6.16 \\
\hline & & & 100 & 84 & 4 & 7.36 & 5.40 & 19.92 & 3.16 & 2.22 & 12.36 \\
\hline
\end{tabular}




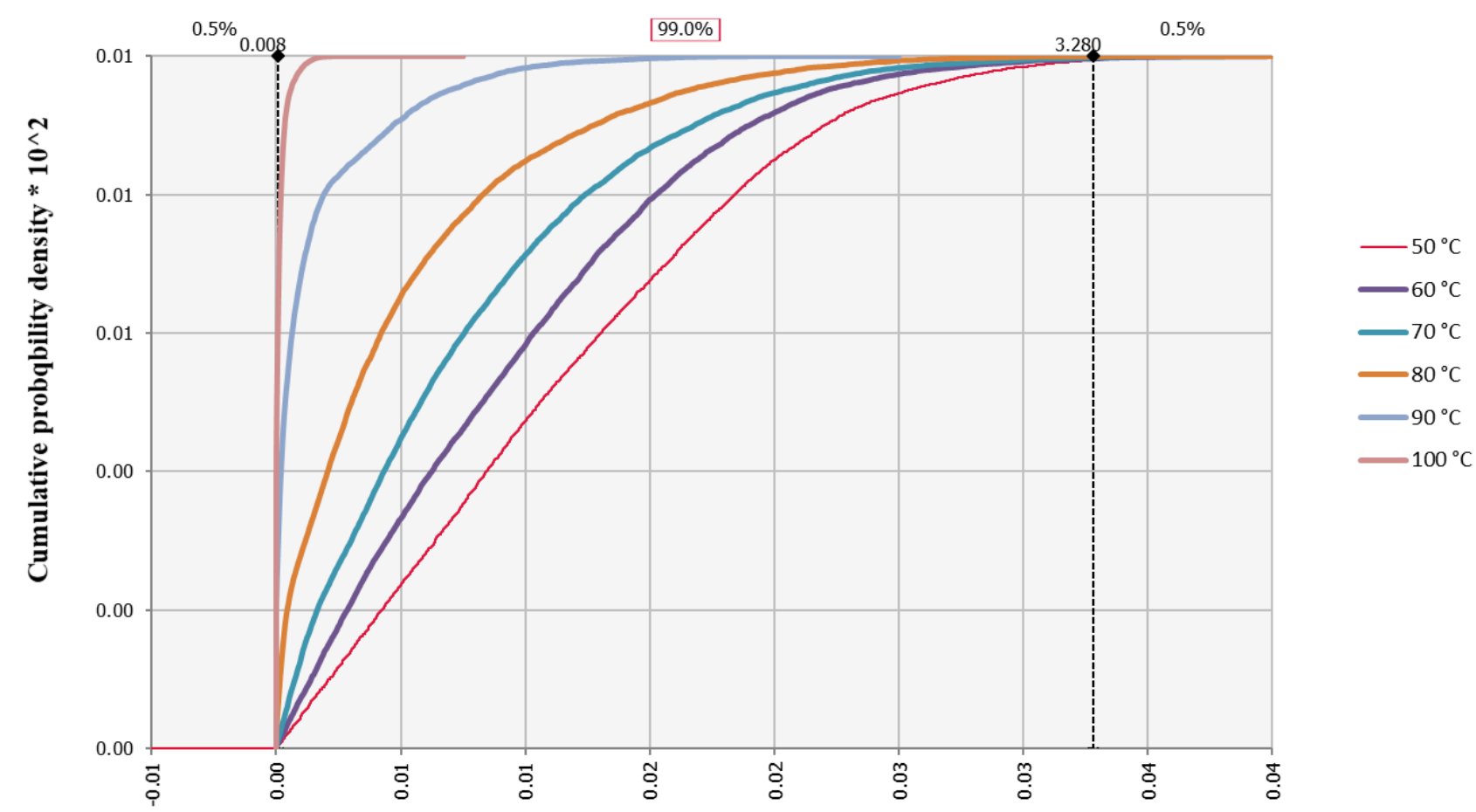

Concentration (log UFC) of $B$. cereus sensu lato during meal preparation * $10^{\wedge} 2$

Figure 1. Evolution of B. cereus sensu lato (log CFU/g) during preparation.

Table 3. Estimation B. cereus sensu lato concentration (log CFU/g of meal) at different preparation temperatures of infant's flour meal.

\begin{tabular}{|c|c|c|c|c|c|c|c|c|c|}
\hline \multirow[t]{2}{*}{$\mathrm{T}^{\circ} \mathrm{C}$} & \multicolumn{4}{|c|}{$\begin{array}{l}\mathrm{CFU} / \mathrm{g} \\
\text { Before preparation }\end{array}$} & \multicolumn{4}{|c|}{ preparation } & \multirow[t]{2}{*}{$\begin{array}{l}\text { ANOVA } \\
\text { analysis }\end{array}$} \\
\hline & $\min$ & median & mean & $99^{\text {th }}$ & min & mean & median & 99th & \\
\hline$=<50$ & 1.729 & 2.489 & 2.615 & 3.705 & & 1.158 & 1.06 & 3.11 & 0.001 \\
\hline 60 & & & & & & 0.939 & 0.828 & 2.908 & \\
\hline 70 & & & & & & 0.746 & 0.584 & 2.756 & \\
\hline 80 & & & & & & 0.4878 & 0.304 & 2.36 & \\
\hline 90 & & & & & & 0.142 & 0.036 & 1.126 & \\
\hline 100 & & & & & & 0.0135 & 0.004 & 0.124 & \\
\hline
\end{tabular}

The Monte Carlo simulations of initial concentrations of toxigenic B. cereus in the infant's flour before preparation were reported in Table 3 . It was assumed at (median $=2.489$; mean $=2.615$; $\left.99^{\text {th }}=3.75\right) \log \mathrm{CFU} / \mathrm{g}$.

After preparation, the eventual toxigenic B. cereus concentrations were reported in Table 3 according to Equation 5. The low values (CFU per $\mathrm{g}$ of prepared meal) were estimated for temperature 100
${ }^{\circ} \mathrm{C}\left(\min =0\right.$, median $=0.004 ;$ mean $=0.135 ; 99^{\text {th }}=$ $1.24 \log \mathrm{CFU} / \mathrm{g}$ ) followed by scenario $90{ }^{\circ} \mathrm{C}$ $\left(\min =0\right.$, median $=0.036 ;$ mean $=0.142,99^{\text {th }}=$ $1.226 \log \mathrm{CFU} / \mathrm{g}$ ) (Table 3). Both of these temperatures are safe for infants, while heating at temperature recommended by the manufacturers is hazardous and no significant effect (ANOVA $P<0.001)$ change in initial concentration was observed (Figure 1). 


\section{CONCLUSION}

Nowadays, the use of infant's flour by parents has known a significant increase. However, in spite of its weak water activity, this food product is nonsterile and several undesirable and pathogenic microorganisms could proliferate there. Therefore, great attention should be paid to the consumption of infant's flour in terms of the occurrence of potential microbial dangers such as spores since it is intended for a sensitive group of consumers (infants).

In this line, this study was conducted to search these bacteria in such food stuff, especially the $B$. cereus sensu lato that are known for their heat resistance. According to the preparation patterns, B. cereus sensu lato could be involved in food poisoning.

Our findings showed that $75 \%$ of infant's flour samples were contaminated with Bacillus. In addition, the results of this paper highlight the effectiveness in reducing the level of $B$. cereus sensu lato compared to the manufacturer's instructions. Thus, until it is difficult to increase a heating temperature, that could reduce the nutritional quality of the infant meal, only the patterns use must be improved. Thus, some recommendations could be established to avoid issues related to this type of bacteria:

- Choose a relevant raw material;

- Improve continuously the process and control it;

- Review the preparation instructions and improve the product solubility at high temperatures;

- Reduce the amount of flour from $200 \mathrm{~g}$ to $100 \mathrm{~g}$ per package;

- Add the storage condition to the packaging.

Finally, as perspectives for this study, additional experiments need to be performed in the future, on: (1) determining the $B$. cereus affiliation into different groups;

(2) studying their growth in the infant's flour meal;

(3) conducting the microbial risk assessment to get in-depth sufficient details about this type of bacteria which will undoubtedly help industries during production process and stores during storage.

\section{REFERENCES}

1. Bigelow, W. D. (1921). The logarithmic nature of thermal death time curves. J. Infect. Dis. 29, 528536. https://www.jstor.org/stable/30082910

2. Buss da Silva, N., Baranyi, J., Carciofi, B. A. M. \& Ellouze, M. (2017). From culture-medium-based models to applications to food: predicting the growth of B. cereus in reconstituted infant formulae. Front. Microbiol. 8, 1799. doi: 10.3389/fmicb.2017.01799

3. Byaruhanga, Y. B., Bester B. H. \& Watson T.G. (1999). Growth and survival of Bacillus cereus in mageu, a sour maize beverage. World J. Microbiol. Biotechnol. 15, 329-333. https://doi.org/10.1023/A:1008967117381

4. Carlin, F, Albagnac, C, Rida, A, Guinebretière, M. H, Couvert O. \& Nguyen-The C. (2013). Variation of cardinal growth parameters and growth limits according to phylogenetic affiliation in the Bacillus cereus Group. Consequences for risk assessment. Food Microbiol. 33, 69-76. DOI: 10.1016/j.fm.2012.08.014

5. Clark, D. \& Shrimpton R. (2000). Complementary feeding, the Code, and the Codex. Food Nutr. Bull. 21, 25-29.

6. Daczkowska-Kozon, E. G., Bednarczyk, A., Biba M. \& Repich K. (2009). Bacteria of Bacillus cereus group in cereals at retail. Polish J. Food Nutr. Sci. 59, 53-59.

7. Guinebretière, M. H., Thompson, F. L., Sorokin, A., Normand, P., Dawyndt, P., Ehling-Schulz, Svensson, B., Sanchis, V., Nguyen-The, C., Heyndrickx, M. \& De Vos, P. 2008. " Ecological diversification in the Bacillus cereus group ». Environ. Microbiol. 10, 851-865. https://doi.org/10.1111/j.1462-2920.2007.01495.x

8. Grawitz M. (2001). Méthodes des sciences sociales (Social science methods). $11^{\text {ème }}$ édition. 2001. Paris: Dalloz.

9. Heini, N. M., Stephan, R., Stephan R. \& Ohler S. (2018). Characterization of Bacillus cereus group 
isolates from powdered food products. Int. J. Food Microbiol. 283, 59-64. https://doi.org/10.1016/j.ijfoodmicro.2018.06.019

10. Jackson, K. M. \& Nazar AM. (2006). Breastfeeding, the Immune Response, and Long-term Health. J. Am. Osteopath. Assoc. 106, 203-207. https://pubmed.ncbi.nlm.nih.gov/16627775/

11. Janštová, B. \& Lukášová J. (2001). Heat resistance of Bacillus spp. spores isolated from cow's milk and farm environment. Acta Vet Brno 70, 179-184. DOI: 10.2754/avb200170020179

12. Mazas, M., López, M., Martínez, S., Bernardo A. \& Martin R. (1999). Heat resistance of Bacillus cereus spores: effects of milk constituents and stabilizing additives. J. Food Prot. 62, 410-413. DOI: $10.4315 / 0362-028 \mathrm{x}-62.4 .410$

13. Membré, J. M. \& Valdramidis V. (2016). Modeling in Food Microbiology. From Predictive Microbiology to Exposure Assessment. ISTE Press Ltd and Elsevier Ltd, UK. https://doi.org/10.1016/B978-1-78548-155-0.50005-8

14. Messelhäusser, U., Frenzel, E., Blöchinger, C., Zucker, R., Kämpf, P. \& Ehling-Schulz, M. (2014). Emetic Bacillus cereus are more volatile than thought: recent foodborne outbreaks and prevalence studies in Bavaria (2007-2013). Biomed Res. Int. 2014:465603

15. Montville TJ, Dengrove R, De Siano T, Bonnet M, \& Schaffner DW. (2005). Thermal resistance of spores from virulent strains of Bacillus anthracis and potential surrogates. J. Food Prot. 68, 23622366. DOI: $10.4315 / 0362-028 x-68.11 .2362$

16. Nauta, M. J. (2001). A modular process risk model structure for quantitative microbiological risk assessment and its application in an exposure assessment of Bacillus cereus in a REPFED. RIVM Report 249106007. Bilthoven, The Netherlands. http://hdl.handle.net/10029/9385

17. NutriFaso, (2007). Cahier des charges d'une farine infantile souhaitant être labellisée NUTRIFASO (Specifications for infant flour wishing to be labeled). Projet NutriFaso, Gret, IRD, ANSA-B.

18. Sadek, Z.I., Abdel-Rahman, M.A., Azab, M.S., Darwesh, O.M., Hassan, M.S. (2018). Microbiological evaluation of infant foods quality and molecular detection of Bacillus cereus toxins relating genes. Toxicol. Rep. 5, 871-877. https://doi.org/10.1016/j.toxrep.2018.08.013.

19. Sanogo, M., Branderhorst, E., Laurent F. \& Trèche S. (1994). La production artisanale des farines infantiles, Expériences et procédés (The artisanal production of infant flours ériences Experiences and processes). Gret, Paris, France; 11.

20. Sarrias, J. A., Valero M. \& Salmeron MC. (2002). Enumeration, isolation and characterization of Bacillus cereus strains from Spanish raw rice. Food Microbiol. 19, 589-595. https://doi.org/10.1006/fmic.2002.0514

21. Savić, D., Ristanović, E., Miljković, S. B., Radaković, S., Jošić, D. \& Lepšanović, Z., (2020). Enterotoxin and emetic toxin genes profiles and genetic diversity of Bacillus cereus isolated from food, environmental and clinical samples in Serbia. Acta Veterinaria, 70, 182-193. DOI: https://doi.org/10.2478/acve-2020-0013

22. Stoeckel, M., Westermann, A. C., Atamer Z. \& Hinrichs J. (2013). Thermal inactivation of Bacillus cereus spores in infant formula under shear conditions. Dairy Sci. Technol. 93, 163-175. https://hal.archives-ouvertes.fr/hal-01201403

23. Valerio, F., De Bellis, P., Di Biase, M., Lonigro, S.L., Giussani, B., Visconti, A., Lavermicocca P. \& Sisto A. (2012). Diversity of spore-forming bacteria and identification of Bacillus amyloliquefaciens as a species frequently associated with the ropy spoilage of bread. Int. J. Food Microbiol. 156, 278285. https://doi.org/10.1016/j.ijfoodmicro.2012.04.005

24. Zhang, Y., Chen, J., Feng, C., Zhan, L., Zhang, J., Li, Y., Yang, Y., Chen, H., Zhang, Z., Zhang, Y., Mei L. \& Li H. (2017). Quantitative prevalence, phenotypic and genotypic characteristics of Bacillus cereus isolated from retail infant foods in China. Foodborne Pathog. Dis. 14, 564-572. DOI: $\underline{10.1089 / \text { fpd.2017.2287 }}$

25. Ziane, M., Couvert, O., Le Chevalier, P., Moussa-Boudjemaa B. \& Leguerinel I. (2016). Identification and characterization of aerobic spore forming bacteria isolated from commercial camel's milk in south of Algeria. Small Ruminant Res. 137, 59-64. https://doi.org/10.1016/j.smallrumres.2016.03.004 
26. Ziane, M., Desriac, N., Le Chevalier, P., Moussa-Boudjemaa B. \& Leguerinel I. (2014). Identification, heat resistance and growth potential of mesophilic spore-forming bacteria isolated from Algerian retail packaged couscous. Food Control 45, 16-21. https://doi.org/10.1016/j.foodcont.2014.04.003

27. Ziane, M., Leguerinel I. \& Membré J.M. (2019). A quantitative microbiological exposure assessment of Bacillus cereus group IV in couscous semolina, Algeria. Microb. Risk Anal. 11, 11-22. https://doi.org/10.1016/j.mran.2018.07.001 